\title{
Study of Molecular Docking of Vitexin in Binahong (Anredera cordifolia (Ten.) Steenis) Leaves Extract on Glibenclamide- CYP3A4 Interaction
}

\author{
Dwitiyanti' ${ }^{1}$ Yahdiana Harahap ${ }^{2}$, Berna Elya ${ }^{3}$, Anton Bahtiar ${ }^{4, *}$
}

Dwitiyanti' ${ }^{1}$ Yahdiana Harahap², Berna Elya ${ }^{3}$, Anton Bahtiar ${ }^{4, *}$

'Graduated Program of faculty of Pharmacy, Universitas Indonesia, Kampus UI Depok, West Java 16424, INDONESIA.

${ }^{2}$ Department of Bioanalysis, Faculty of

Pharmacy, Universitas Indonesia, Kampus UI Depok, West Java 16424, INDONESIA.

${ }^{3}$ Department of Phytochemistry, Faculty of

Pharmacy, Universitas Indonesia, Kampus UI

Depok, West Java 16424, INDONESIA.

${ }^{4}$ Department of Pharmacology and

Toxicology, Faculty of Pharmacy, Universitas

Indonesia, Kampus UI Depok, West Java

16424, INDONESIA.

\section{Correspondence}

\section{Anton Bahtiar}

Department of Pharmacology and

Toxicology, Faculty of Pharmacy,

Universitas Indonesia, Kampus UI Depok,

West Java 16424, INDONESIA.

E-mail: anton.bahtiar@farmasi.ui.ac.id

History

- Submission Date: 13-09-2019;

- Review completed: 09-10-2019;

- Accepted Date: 16-10-2019.

\section{DOI : 10.5530/pj.2019.11.227}

Article Available online

http://www.phcogj.com/v11/i6s

Copyright

(C) 2019 Phcogj.Com. This is an openaccess article distributed under the terms of the Creative Commons Attribution 4.0 International license.

\begin{abstract}
Introduction: Diabetes Mellitus is a disease that has a high prevalence in Indonesia. About 90-95\% of all diabetes cases were caused by the failure or incapability of insulin target cells to respond to the insulin in normal state. The use of glibenclamide antidiabetic drugs with herbs has been occurred frequently in the community. Vitexin, one of active compounds in binahong (Anredera cordifolia (Ten.) Steenis) leaves, has been known to have an antidiabetic effects. This study aimed to determine the molecular docking interaction of glibenclamide and vitexin in binahong leaves against CYP3A4 as antidiabetic drug. Method: Molecular docking methods were carried out using Autodock Vina software and interaction was visualized using discovery studio. Results: The study indicated that the value of glibenclamide complex free energy with CYP3A4 was $-3.2 \mathrm{kcal} / \mathrm{mol}$ and the stability has increasing to $-4.4 \mathrm{kcal} / \mathrm{mol}$ after docked with vitexin. The glibenclamide and vitexin complexes had $7 \mathrm{Pi}$ alkyl hydrophobic bonds, 1 hydrocarbon hydrogen bond $1 \mathrm{Pi}$-cation electrostatic interactions, other interactions between $\mathrm{Pi}$ bond and sulfur atoms in cysteine amino acid residues, Pi bond interactions in phenylalamin aromatic groups with electron pairs oxygen atom. Conclusion: This study concluded that vitexin could improve glibenclamide stability.

Key words: Molecular docking, Diabetes mellitus, Glibenclamide, Vitexin.
\end{abstract}

\section{INTRODUCTION}

Diabetes mellitus is a disease caused by various factors. Diabetes mellitus is caused by insulin resistance, insulin deficiency and abnormal insulin secretion. Diabetes mellitus is a metabolic disorder characterized by high levels of glucose in the blood (hyperglycemia) and the detection of fat, fat, and protein. ${ }^{1}$ International Diabetes Federation (IDF) data for 2017 stated that diabetes mellitus (DM) sufferers in the world are estimated to continue to increase by $48 \%$ from 425 million sufferers in 2017 to increase by around 629 million in 2045 , while in Asia according to IDF showed an increase of $84 \%$ from 82 million sufferers in 2017 increased to 151 million in 2045. Indonesia ranks 6th out of 10 as the largest diabetes populated countries in the world with 10 million sufferers. ${ }^{2}$

Diabetes treatment therapy is consisted of oral antidiabetic drugs that can be used with one type of drug or combination. Drugs that are widely used in the treatment of diabetes mellitus, one of which is sulfonylureas. One of the drugs used by people with type 2 diabetes is glibenclamide from sulfonylurea group. Glibenclamide is one of the most well-known antidiabetic drugs and belongs to the sulfonylurea group which reduces oxygen levels by production of insulin by Langerhans beta cells. ${ }^{3}$ In addition, drugs derived from natural ingredients can be a therapeutic choice by patients with diabetes mellitus. The use of natural materials as adjuvant to DM treatment has long been carried out by the people of Indonesia. One of the natural ingredients that has the potential to reduce blood sugar levels is Binahong plant

Binahong pharmacological activities included antihyperlipidemia, anti-inflammatory, analgesic, and antipyretic. ${ }^{4}$ Other studies reported that binahong leaf extract can inhibit $a$-glucosidase with an IC50 value of $54.24 \mu \mathrm{g} / \mathrm{mL} .^{5}$ Binahong leaf methanol extract at a dose of $50 \mathrm{mg} / \mathrm{kg}$ body weight and 200 $\mathrm{mg} / \mathrm{kg}$ body weight could reduce the blood glucose levels of alloxan-induced mice on the 7th day by $61.02 \%$ and $60.68 \%$, respectively. Meanwhile, on the 14 th day a decrease in glucose levels by $75.64 \%$ and $66.61 \%$ was observed, histologically could repair $\beta$-pancreatic cell damage. ${ }^{6}$

The pharmacological effects of Binahong plants can be used as an alternative to reducing blood glucose levels. The amount of active content of Binahong plants is possible for interaction if given together with glibenclamide. Flavonoid glycoside compounds found in binahong leaves, namely vitexin (8-beta-Dglucopiranosilapigenin) are active substances that are responsible as antidiabetic agents. However, in many cases the combination of herbs with synthetic drugs causes interactions. Compounds contained in herbs can interact with synthetic drugs if used at the same time. Previous studies have shown that apigenin flavonoids were CYP3A4 $4^{7}$ enzymes inhibitors, and glibenclamide were primarily metabolized by CYP3A4 enzymes. ${ }^{8}$

One way that can be done to determine the effect of the combination of glibenclamide with herbal 
adjuvant in the treatment of diabetes is through molecular docking simulations to predict bond conformation and binding affinity formed between receptors and ligands which are very instrumental in further drug development. ${ }^{9}$

\section{MATERIALS AND METHODS}

\section{Tools}

A set of laptops with Intel (R) Core (TM) i7-4720 HQ CPU @ 2.60GHz, $-2.60 \mathrm{GHz}$ processor, 16.0GB RAM memory, with operating system windows 8.1 Pro Home 64-bit connected to the internet connection and linux operating system ubuntu (32-bit). Chimera 1.13, YASARA version 10.1.8, AutoDockTools-1.5.6, Discovery Studio Visualizer version 17.2.0.16349 (http://accelrys.com/), Protein Data Bank (http:// www.rcsb.org/pdb) and PubChem (http://PubChem.ncbi.nlm.nih. gov).

\section{Material}

This study used a 5G5J pdb receptor which was downloaded from RSCB PDB (http://www.rcsb.org/pdb). The glibenclamide and vitexin as ligand compounds wereand downloaded from PubChem. ${ }^{10}$

\section{Research procedures}

The procedure of this study was carried out by preparation of ligand structure using Chimera with the aim of cleaning receptors and ligands from all residues contained in these receptors and ligands. Then the method validation and re-docking was done using Autodock Vina which was aimed to validate the method that will be used. The validation was also done to decide whether the method can be resumed or not to the next phase and to search for pocket cavity receptors.

The next process was molecular docking simulation or can be referred as virtual screening, aimed at finding drug candidates observed from ChemPLP score values. The next stage is the analysis of results based on ChemPLP score values. The visualization was generated from molecular docking simulations using the Discovery Studio Visualizer software.

\section{RESULT}

\section{Receptor structure preparation}

The receptor used in the study was CYP3A4 protein. The a-glucosidase protein used is downloaded through the Protein Data Bank at the site http://www.rcsb.org/pdb with PDB ID: 5G5J. The selection of 5G5J receptors based on experimental data was organism data (s) which stated Homo sapiens (humans) and has a resolution value of $2.6 \AA .^{11}$ The results are shown in Figure 1.

\section{Ligand structure preparation and optimization}

The ligands that used were first downloaded in three-dimensional (3D) format with the .sdf format from PubChem via https://pubchem.ncbi. nlm.nih.gov/. After all files are downloaded, ligand preparation was done using the Chimera software. All ligands including comparison ligands were prepared and reshaped in the pdbqt file format. The results are shown in Figures 2 and 3.

\section{Method validation and re-docking}

Method validation and re-docking was done used Autodockvina with native ligands and receptors. The results of re-docking were the default results from native ligands with receptors. It was used in virtual screening for 2 ligands, namely vitexin and glibenclamid. Furthermore, from the re-docking stage also obtained Gibbs free energy $(\Delta \mathrm{G})$ redocking results of $-5.2 \mathrm{kcal} / \mathrm{mol}$. Then the results were analyzed through YASARA to observe the RMSD (Root Mean Square Deviation) value of heavy atoms and the value was $1.9391 \AA$.

\section{Molecular docking results analysis}

The results analysis was carried out through screening of Gibbs free energy $(\Delta G)$ of each docking compound by selecting the conformational compound that had the lowest Gibbs free energy $(\Delta G)$. Gibbs free energy $(\Delta G)$, generated from the formation of receptorligand complex, could show the affinity of the ligand for the receptor. The docking results can be observed in Table 1 of the 2 analyzed ligands and 1 complex (glibenclamid and vitexin), the lowest Gibbs free energy $(\Delta \mathrm{G})$ observed was in the complex compounds, namely glibenclamid

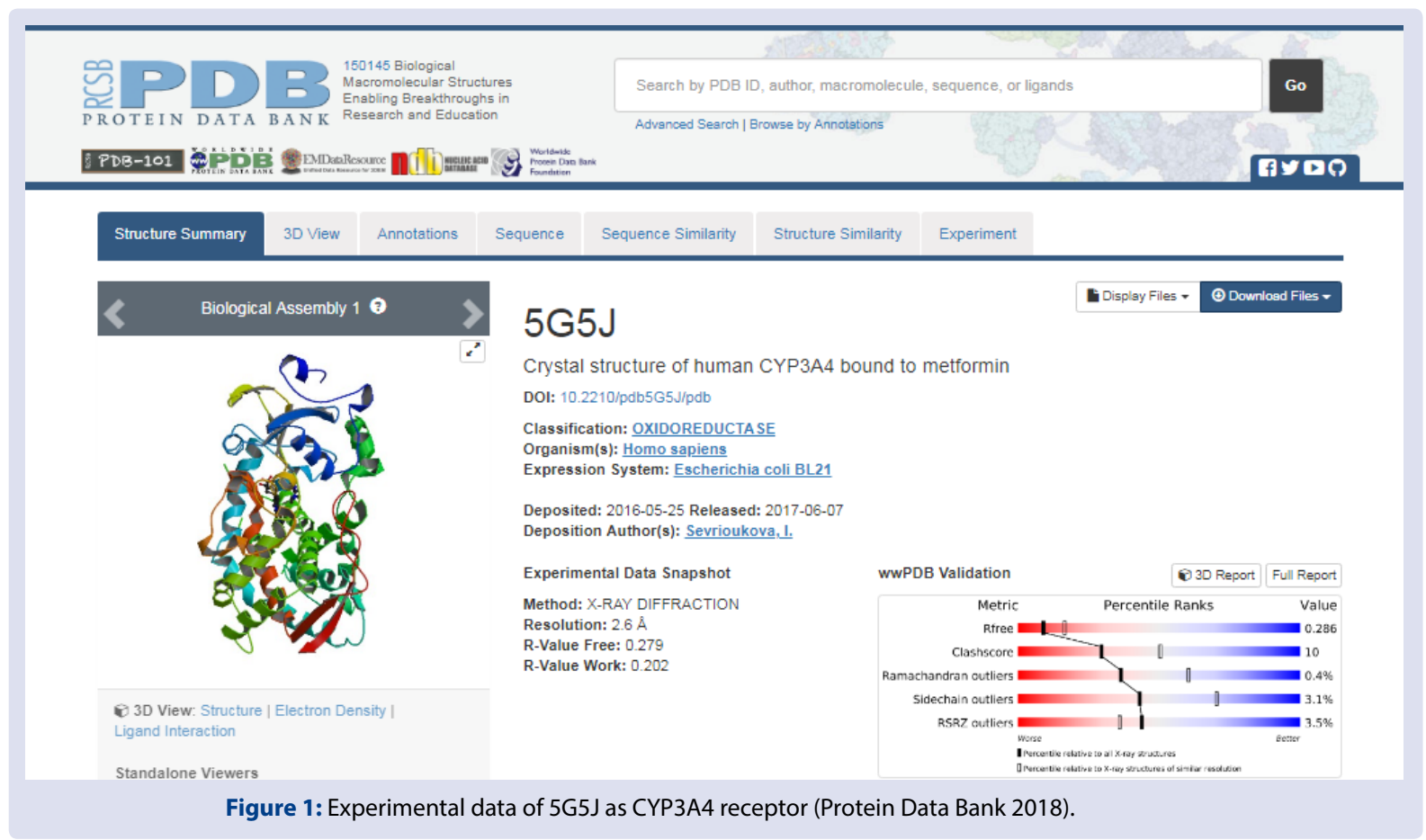




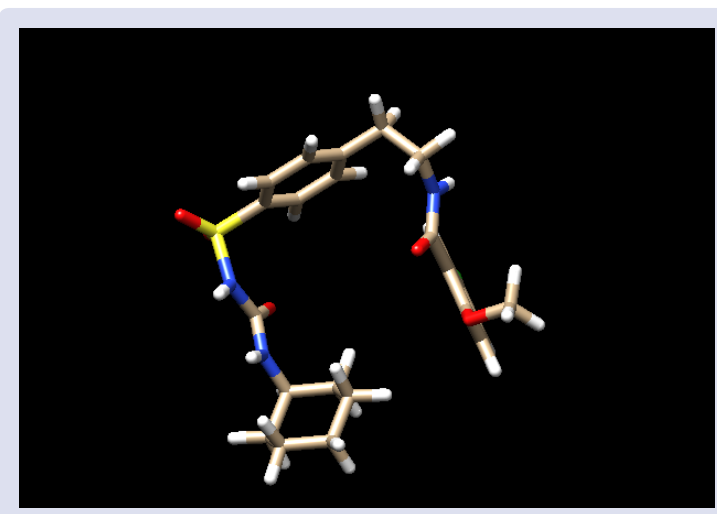

Figure 2: Glibenclamide ligand (pubchem.ncbi.nlm.nih.gov)

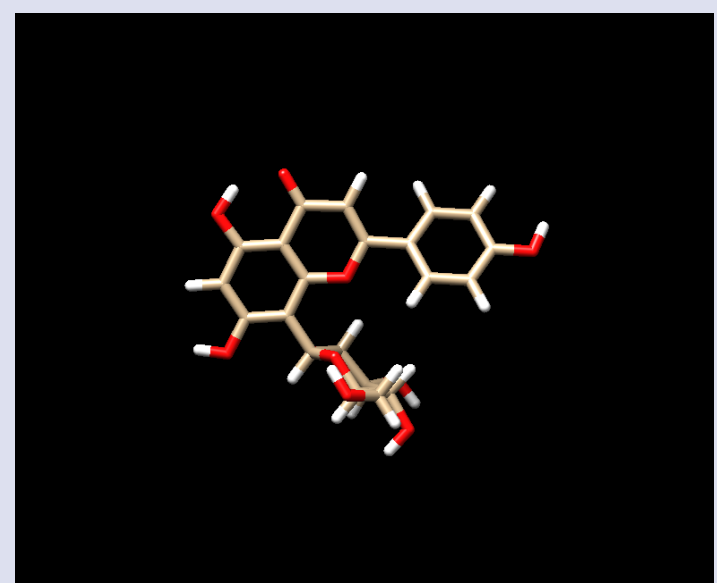

Figure 3: vitexin Ligand (pubchem.ncbi.nlm.nih.gov).

Table 1: Molecular docking simulation results between Glibenclamid, vitexin and combination compounds (glibenclamid and vitexin) with CYP3A4 using vina autodock.

\begin{tabular}{ccc}
\hline No & Ligand & $\begin{array}{c}\text { Gibbs free energy }(\Delta \mathrm{G}) \\
(\mathrm{kcal} / \mathrm{mol})\end{array}$ \\
\hline 1 & Glibenclamid + vitexin & $-4,4$ \\
2 & Glibenclamid & $-3,2$ \\
3 & Vitexin & $-3,2$ \\
\hline
\end{tabular}

and vitexin complexes that bind to CYP3A4 receptors with a ChemPLP score of $-4,4 \mathrm{kcal} / \mathrm{mol}$, while the Gibbs free energy $(\Delta \mathrm{G})$ glibenclamide with $-3.2 \mathrm{kcal} / \mathrm{mol}$ receptors and vitexin with receptors is $-3.2 \mathrm{kcal} / \mathrm{mol}$.

\section{DISCUSSION}

The selection of 5G5J receptors based on experimental data was organism data (s) which stated Homo sapiens (humans) and had a resolution value of $2.6 \AA$. Resolution value is one of the receptors selection parameters. Structure with resolution values less than $3 \AA$ may affect the stability of the receptors. When performing molecular docking, lower receptor resolution value may generate better receptor stability. The resolution value on PDB ID stated that the protein structure has the same pose as the structure of the X-ray/original protein. ${ }^{12}$ The 5G5J receptor binds to 2 ligands namely Protoporphyrin IX Containing Fe and Metformin which can be said to be native ligands.

The ligands that used were first downloaded in three-dimensional (3D) format with the .sdf format from PubChem via https://pubchem. ncbi.nlm.nih.gov/. After all files were downloaded, ligand preparation was done using the Chimera software. All ligands was also including comparison ligands which were prepared and reshaped in the. pdbqt file format. This file format change was aimed to adjust to Autodock Vina which used the .pdbqt file format so that the simulation process could run.

Method validation and re-docking using Autodockvina with native ligands and receptors aim to determine whether the docking method/ protocol used was acceptable. The results of re-docking were the default results from native ligands with receptors. It was used in virtual screening for 2 ligands, namely vitexin and glibenclamide. Furthermore, from the re-docking stage also obtained Gibbs free energy $(\Delta G)$ re-docking results of $-5.2 \mathrm{kcal} / \mathrm{mol}$. Then the results were analyzed through YASARA to see the RMSD (Root Mean Square Deviation) value of heavy atoms and the value obtained was $1.9391 \AA$. This means the method used was acceptable because the RMSD value was less than $2.0 \AA^{13}$

RMSD value of heavy atoms showed the value of deviation between a ligand conformation structure with native ligands. Smaller deviation means smaller error in the prediction of the interaction of the ligand with protein. It could be said that the conformation of the ligand with native ligand has the same and parallel structure and atoms. The results of the validation showed that the RMSD value of heavy atoms 1.9391 A was still in the range of allowable RMSD values that is less than 2 $\AA$. After that is fulfilled, the method validation process can be used to perform virtual screening with glibenclamide and vitexin.

Figure 4 is the result of validation using YASARA, it can be seen that there were 2 compounds, namely docking ligand and native ligand. Compounds with yellow carbon atoms were docking ligands while compounds with blue carbon atoms were native ligands. After the validation method/protocol docking stage was accepted, virtual screening was performed. This stage was aimed to obtain Gibbs free energy $(\Delta G)$ based on the interaction between the ligand with the receptor. The receptors used were the same receptors on validation and the ligands used were glibenclamide and vitexin.

Analysis of the results was carried out through screening of Gibbs free energy $(\Delta G)$ of each docking compound by selecting the conformational compound that had the lowest Gibbs free energy $(\Delta G)$. Gibbs Free energy $(\Delta G)$ generated when the receptor-ligand complex was formed can show the affinity of the ligand for the receptor. The affinity of the ligand was shown to be negative, which means that if the affinity for the receptor was high, the Gibbs free energy $(\Delta G)$ was getting smaller, whereas if the affinity was small, the Gibbs free energy $(\Delta G)$ was greater.

Table 1 shows the Gibbs free energy $(\Delta G)$ which was evaluated and was the result of docking simulation using the CYP3A4 receptor. The Gibbs free energy $(\Delta G)$ used was the lowest value, because the low ChemPLP score shows good stability and high affinity in the molecular docking process. ${ }^{13}$ The docking results can be observed in Table 1 of the 2 of analyzed ligands and 1 complex (glibenclamide and vitexin), the lowest Gibbs free energy $(\Delta \mathrm{G})$ was in the complex compounds namely glibenclamide and vitexin complexes that bind to CYP3A4 receptors with a ChemPLP score of $-4,4 \mathrm{kcal} / \mathrm{mol}$, while the Gibbs free energy $(\Delta \mathrm{G})$ glibenclamide with $-3.2 \mathrm{kcal} / \mathrm{mol}$ receptors and vitexin with receptors is $-3.2 \mathrm{kcal} / \mathrm{mol}$. These results indicate that the stability between the complex compound glibenclamide and vitexin with the CYP3A4 receptor was better and had a higher affinity compared to the use of a single drug.

The glibenclamide and vitexin complex had 7 Hydrophobic Pi-type Alkaline bonds, 1 Hydrocarbon-type hydrogen bond, 1 Pi-cation electrostatic interaction, other interactions between $\mathrm{Pi}$ bonds with sulfur atoms in cysteine amino acid residues, interaction of Pi bonds in phenylalamin aromatic groups with oxygen atom electron pairs. 


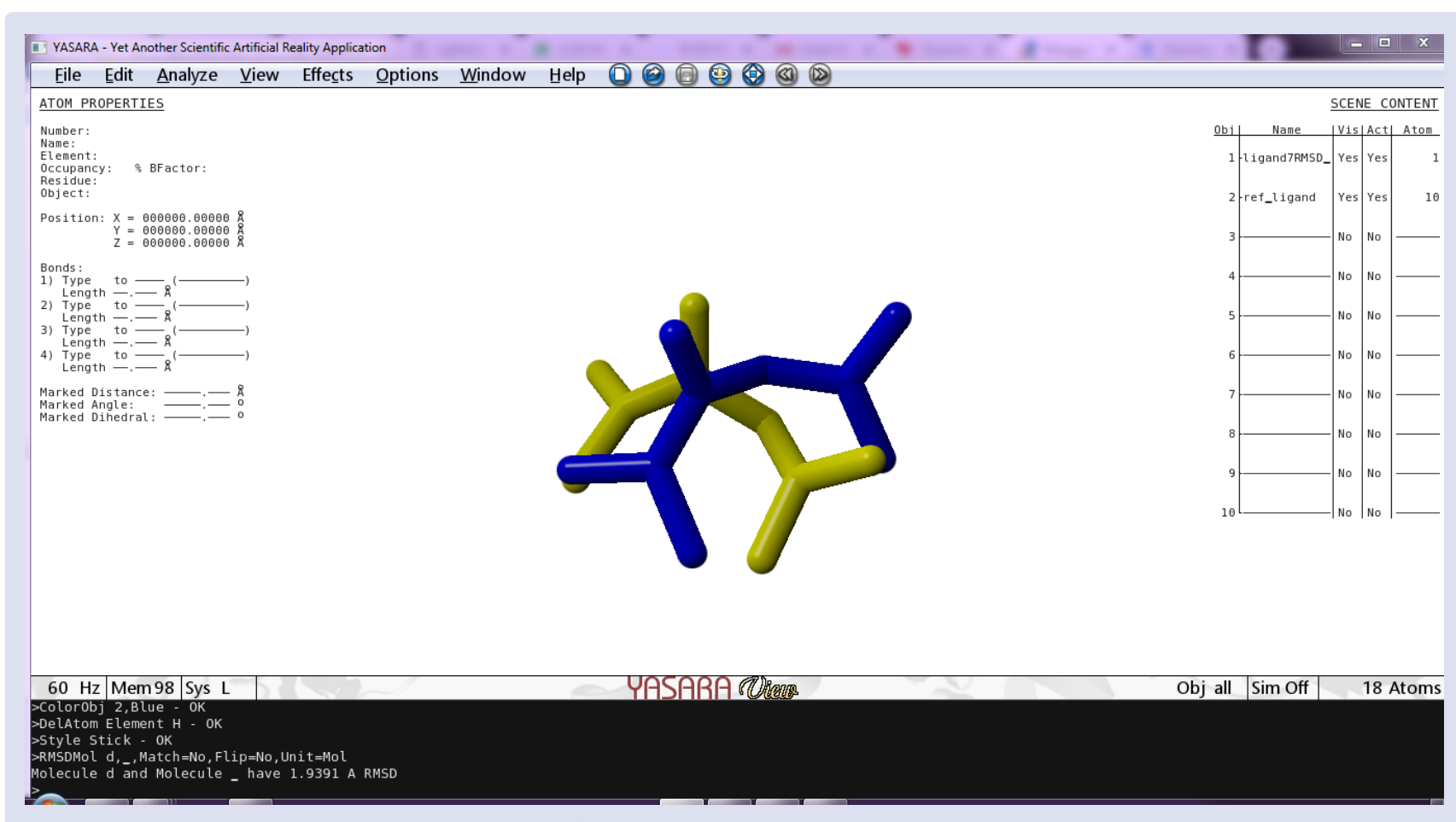

Figure 4: Superpose of validation results for docking ligand structures (yellow) with native ligand structures (blue).

\section{CONCLUSION}

vitexin could increase the stability of the action of glibenclamide against CYP3A4 receptors as antidiabetic.

\section{ACKNOWLEDGEMENT}

This research was support by The Ministry of Research, Technology and Higher Education of Republic Indonesia Research Grant (Penelitian Doktor) 2019.

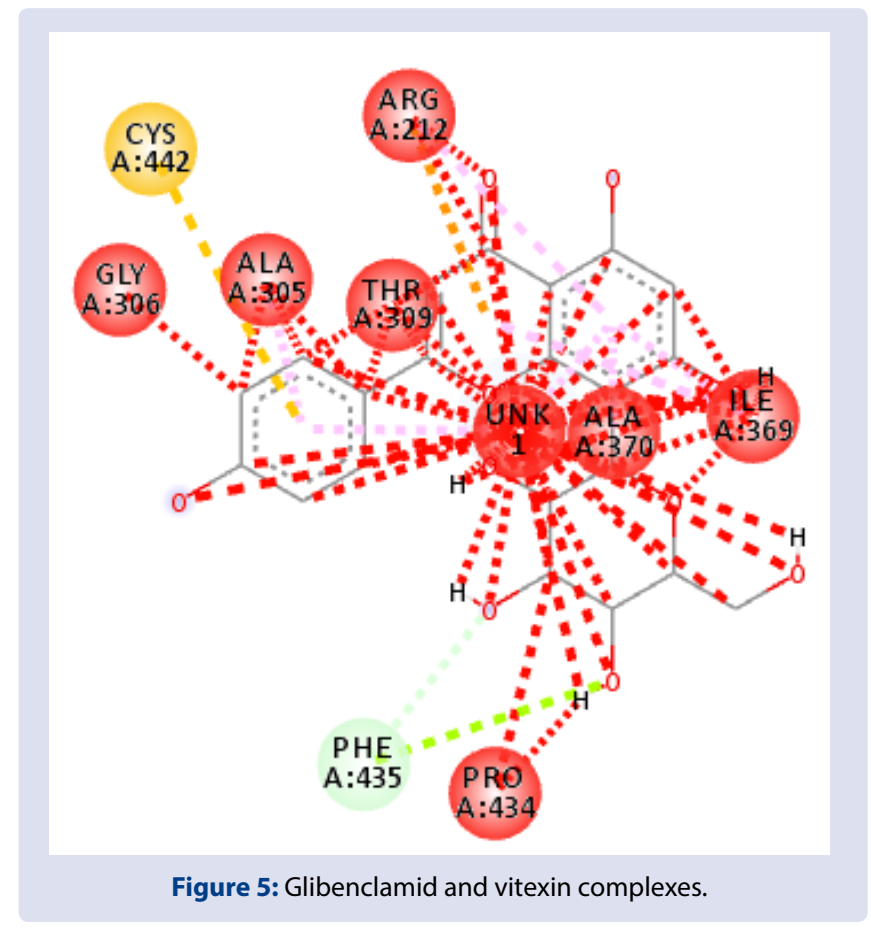

\section{REFERENCES}

1. Dipiro JT, Wells BG, Schwinghammer TL, Dipiro CV. Pharmacotherapy handbook. Inggris: McGraw-Hill Education Companies. 2005.

2. International Diabetes Federation. Eighth edition 2017. Retrieved from http:// www.diabetesatlas.org/resources/2017-atlas.html

3. Katzung BG, Trevor AJ. Basic \& Clinical Pharmacology Thirteenth Edition. McGraw-Hill Education Companies. 2015.

4. Abou Zeid AHS; Soliman FM; Sleem AA; Mitry MNR. Phytochemical and bioactivity investigations of the aerial parts of Anredera cordifolia (Ten.) Steenis. 2007. 
5. Elya B, Handayani R, Saurisari R, Azizahwati Hasyyati US, Permana IT, et al. Antidiabetic activity and phytochemical screening of extracts from Indonesian plants by inhibition of alpha amylase, alpha glucosidase and dipeptidyl peptidase IV. Ansinet. 2005;18(6):279-84.

6. Sukandar EY, Qowiyah A, Larasati L. Effect of methanol extract hearhleaf madeiravine (Anredera cordifolia (TEN.)STEENIS) leaves on blood sugar in diabetes mellitus model mice. 2011;1(4):1-10

7. Basheer L, Kerem Z. Interactions between CYP3A4 and dietary polyphenols. Oxidative Medicine and Cellular Longevity. 2015.

8. Naritomi Y, Terashita S, Kagayama A. Identification and relative contributions of human cytochrome P450 isoforms involved in the metabolism of glibenclamide and lansoprazole: Evaluation of an approach based on the in vitro substrate disappearance rate. Xenobiotica. 2004;34(5):415-27.
9. Trott O, Olson JA. Software news and update autodock vina: Improving the speed and accuracy of docking with a new scoring function, efficient optimization, and multithreading. Journal of Computational Chemistry. 2009;30(7):1174-8

10. PubChem Compound NCBI. 2018. http://pubchem.ncbi.nlm.nih.gov/. Diakses 14 Maret 2018

11. Sahu R, Shukla N. In-silico analysis of different plant protein and their essential compound with sulfonylurea binding protein of $\beta$-cells of homo sapiens for curing diabetes mellitus type ii disease. European Chemical Bulletin. 2014;3(6):568-76

12. Marcou G, Rognan D. Optimizing fragment and scaffold docking by use of molecular interaction fingerprints. Journal of Chemical Information and Modeling. 2007;195-207.

13. Purnomo H. Kimia Komputasi untuk Farmasi dan IImu Terkait: Uji In Siliko Senyawa Antikanker. 2013. Yogyakarta: Pustaka Pelajar.

\section{GRAPHICAL ABSTRACT}

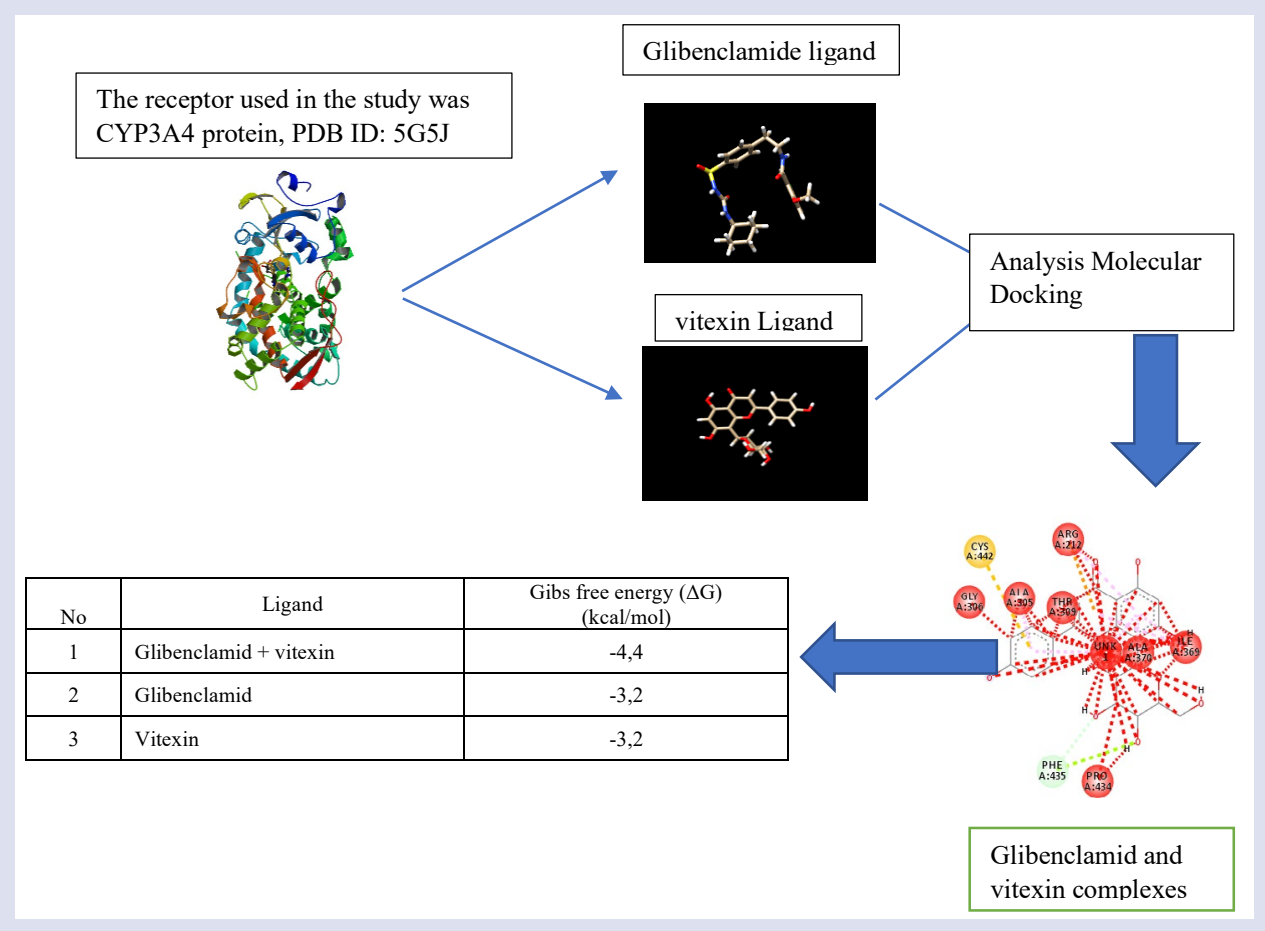

\section{SUMMARY}

- The validation showed that the RMSD value of heavy atoms $1.9391 \AA$ was still in the range of allowable RMSD values that is less than $2 \AA$.

- the stability between the complex compound glibenclamide and vitexin with the CYP3A4 receptor was better and had a higher affinity compared to the use of a single drug.

- vitexin could increase the stability of the action of glibenclamide against CYP3A4 receptors as antidiabetic.

- The glibenclamide and vitexin complex had 7 Hydrophobic Pi-type Alkaline bonds, 1 Hydrocarbon-type hydrogen bond, 1 Pi-cation electrostatic interaction, other interactions between Pi bonds with sulfur atoms in cysteine amino acid residues, interaction of $\mathrm{Pi}$ bonds in phenylalamin aromatic groups with electron pairs oxygen atom.

\section{ABOUT AUTHORS}

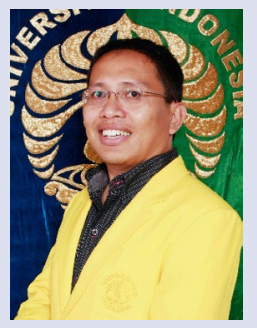

Dr. Anton Bahtiar, M.Biomed., Apt. Obtained his Ph.D. degree in 2010 from Nara Institute of Science and Technology, Japan. Currently, He is lecturer and researcher at faculty of pharmacy, University of Indonesia since 1998. He is also a head of Pharmacology and Toxicology Laboratory. His research projects are focus on Herbal medicine, and tried to solve the mechanism of action of herbal medicine, especially for osteoporosis and menopause. 


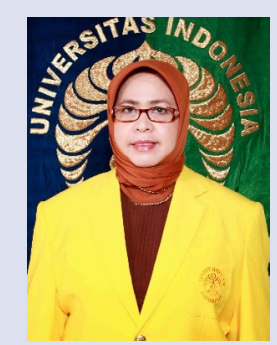

Prof. Dr. Yahdiana Harahap, M.Si., Apt. got her undergraduate degree from Indonesian University in 1987 and finished her PhD from Bandung Institute of Technology in 2003. She is positioned as Professor at Pharmacy at Faculty of Pharmacy Indonesian Univesity. Her research is in Pharmaceutical Chemistry Analysis, especially Bioanalysis and DNA-Adduct Analysis.

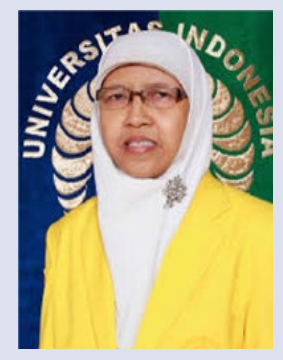

Prof. Dr. Berna Elya, M.Si., Apt. Professor and Head of Phytochemistry and Pharmacognosy, Faculty of Pharmacy, Universitas Indonesia (UI) Depok, West Java, Indonesia. She is expert in the area of Pharmacognosy and Phytochemistry, working in drug discovery of herbal plants, extraction technology, structure elucidation, and degenarative disease such as diabetes mellitus, antyhypertension, and cholesterol.

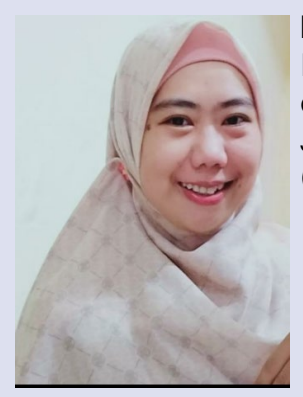

Dwitiyanti, M.Farm., Apt. a Doctoral Student at Department of Pharmaceutical Sciences, Faculty of Pharmacy, Universitas Indonesia, Depok, West Java, Indonesia, and also as a lecturer at Department of Pharmacy, Faculty of Pharmacy and Sciences, University of Muhammadiyah Prof. Dr. HAMKA, East Jakarta, Indonesia. The doctoral research focused on The Influence Of Binahong (Anredera Cordifolia (Ten.) Steenis) Extract On Pharmacodynamics And Pharmacokinetic Glybenclamide.

Cite this article: Dwitiyanti, Harahap Y, Elya B, Bahtiar A. Study of Molecular Docking of Vitexin in Binahong (Anredera cordifolia (Ten.) Steenis) Leaves Extract on Glibenclamide- CYP3A4 Interaction. Pharmacog J. 2019;11(6)Suppl:1471-6. 